\title{
Investigation for Countermeasures and Ways of Cultivating Innovative Students of Art Design in University
}

\author{
Wang Zhaocheng \\ Software College of Zhengzhou University \\ Zhengzhou City, Henan Province, China. Zip Code: 450002 \\ E-mail: iesqwang@zzu.edu.cn; chitudouxhi@163.com
}

\begin{abstract}
Specialty of art design has highly integrated disciplines and more strongly practicing of professional technical skills. Along with the social demands for higher professional is greater today, the educators of University shoulder a mission of the education and training of creative students for art design. In view of the current situation and the analysis of existing problems, the changing of the concept of training education and the ways of cultivating creative students of art design are reached in the paper and presented some valuable viewpoint for discussion.
\end{abstract}

Keywords-Art design; Cultivation of innovative talents; Practice teaching mode; Cases-driven teaching; Creative thinking

\section{Cultivation OF PROFESSiOnal InNOVATIVE TAlENTS IS THE CALL OF THE TIMES}

Today, facing the challenges of the rapid development of science and technology in the world, university education in developing the spirit of innovation and cultivating creative talents takes on a special mission, and education and cultivating the spirit of innovation must be referred to the relationship between the rise and fall of the Chinese nation high to know ${ }^{[1]}$. This is the calling of our time.

Innovation is a process of creative work, not created to also talk about innovation. For the civilization and progress of human society, it can be called the creating of a valuable and unprecedented new mental or physical product to be innovation. The cultivating of innovative talents is also the cultivating them with innovative spirit or sense, creative thinking and innovative ability, while the core is to develop creative thinking ${ }^{[2]}$. But the sense of Innovation is formed by a long-term, persistent education of Outlook on life and values The development of creative thinking and ability is easy to resolve "how to innovate" problem. So that is figuring out how to put innovative ideas, theory and design into actual mental product or physical product (such as written in a literary composition, spectral music, form a painting or create a variety of patented products, etc.).

Creativity is the premise of creation and source of power. For the cultivation of creative talents, it is of crucial significance. Another aspect of innovative consciousness and innovative abilities must have creative thinking as a basis. Due to leave the creative thinking, innovation would be unrealistic. And it became not to be a source of the generation of spiritual or physical products. Creativity is just a matter of the so-called effectiveness of mindlessness, or even be in vain without brute force. So in that sense, the creative thinking is the basis of innovative consciousness and ability, and it is also the core.

Creative thinking would be possessed the most basic quality of creative talents. The cultivating core is to develop creative thinking. In cultivating of the course, it must hold fast to this main problem by surrounding the core to be considered or studied the cultivation. While thinking, intuitive thinking and logical thinking - all of three basic forms are indispensable, there is no distinction between high and low level, and each other differ only by thinking materials and processing methods. In fact, there are mutually supportive and interdependent relationships among the three types of thinking. The result of the one-sided emphasis on logical thinking is not only greatly weakened the imagination and intuition, and that is not healthy for the development of logical thinking itself. But that puts emphasis on the each training of logical thinking for the cultivation of the University students, it must be impossible to establish a correct training model. That is, three kinds of thinking skills should be given good trainings, it is impossible as such to do.

To meet the urgent needs of the creative talents of art design in today's society, this paper is mainly focused on current situation of talent cultivation of art design in University, and in conjunction with our teaching and training practice, the training ideas and some methods of creative talents have been usefully explored to cultivate and promote the innovative design ability of students.

\section{ANALYSIS OF CURRENT SITUATION FOR TALENT Cultivation}

The training professional talent of Art design has very strong professional and practical features, and on, and also highly requires to composite type and relative training process. It not only needs more subject (such as computer science, engineering, psychology, market marketing, etc.) cross fusion, 
and to upgrade experience capacity and appreciation level for works, more need depth fusion of knowledge, technology and Humanity art in design aspects. Therefore, the traditional way of training needs reformation to follow in the age footsteps of rapid development, as the innovation of training system, modes and contents, etc. Currently, the traditional training students of Art design in University most is to instruct pure theory mainly, or art theory courses opened partial more, and to phase supporting of teaching way also compared single. As such a situation must be lack of the innovation thinking and consciousness of penetration and foster for students, then hinder them on art of creative understanding and on art creation practice activities of again processing or again created ${ }^{[3]}$.

Today, with the fast development of information technology, Internet technology and 3D virtual technology applied increasingly broad and deep, 3D Visual pattern has become the future direction of development of art and design. Based on the creativity of cultural and creative industries formed have been gradually developed into a new industry. The other hand, with the deepening of teaching classroom with information technology equipment, dissemination of advanced design concepts and design products by online video and image way, not only enriches the teaching content and raises the teaching effect, also broadens students ' creative vision. And then evoking shock and impact arouse the curiosity and creative thinking of the students. However, there are some problems to be solved urgently still on teaching models and methods.

The first, the shortcomings of teaching ideas, teaching models and methods are difficult to meet the new standard requirement of innovative society. In response to the phenomena of Impulsive design idea, serious copy plagiarism, works applied mechanically, it is very necessary to research training way with new teaching and training ideas to promote the students ' creative thinking ability. The Second, combining curriculum content designed with real social needs is not close enough, so that graduated students are intellectually rich, but actual combat capability poor. As to say that "All in mind, but hands too slow to do it", it is difficult to meet the actual needs of employers to play a specific design work. Due to existing the social contradictions of high demand and low supply of talents, it is making graduates difficult to seek employment or entrepreneurship.

\section{CReative Ways And Methods of Talent Cultivation} OF ART DESIGN

\section{A. Updating knowledge architecture and constructing framework of the cultivating innovative talents}

For changing the traditional thinking of personnel training to emphasizing on art design practices, products and services of social features, it is very important to updated knowledge architecture and then to build a framework of the cultivating innovative talents. 1) Some new design theory and methods are updated or integrated into the curriculum and teaching plan with new design ideas. 2) The changing traditional art teaching mode of art theories is a too bias, and neglect of cultivation for the students ' practical ability ${ }^{[4]}$.
With the increasing diversity of art design diversity fused, the cultivating of innovative talents should be based on the development of their own advantages. For public courses should be properly opened, should get some credits for art design and have the autonomy of choosing public courses to increase practice time and space. That will be more conducive to perfection of design knowledge systems. For example, in order to closely linked the pulse of times with enlighten students' ability to innovate, Arts economics, Java programming, CSS Web design, consumer psychology, virtual reality design, public or elective course would be opened. Teaching design theory lessons at the same time, it should increase the design and practice of machine time units and credits to train students' ability, so that enhances the level of students to have a more comprehensive knowledge of innovation.

\section{B. Expanding the connotation of practical teaching, paying attention to the cultivation of creative thinking}

Practice teaching is the practical application of theoretical knowledge and a feature that art design differs from other disciplines. For the education and training practice ability or theory of art and design will directly reflect the quality of gradates and how to meet social needs, overcoming the culture of students' intelligence but poor combat capability, so expanding the connotation of practical teaching in the major scale and paying attention to the cultivation of creative thinking, is the way to deal with the requirement of cultivating innovative talents today.

In training project, practical teaching types is mainly divided into: 1) training course based on the course content scheduled unit; 2) comprehensive practice course based on blending knowledge; 3) based on the comprehensive training part of the graduation requirements. They all have time to be plan and need assessment and credits. But to encourage students to design and innovation should not ignore the active participation in the various practical activities out of class, such as free time on computer, designing in a teamwork under the guidance of teachers, voluntary subject, etc. Problem is that under the present teaching system, it is difficult to mobilize most of the enthusiasm of the students to make full use of spare time to create design, unless they have made outstanding achievements that have been recognized by social or official. Therefore, the setting artistic courses should pay more attention to practice and expand the connotation of practical teaching for various innovative practices courses at different stages of the term. And further to emphasized the leading role of educators in teaching, let students contact with new design concepts in the first time from teaching to improve the level of appreciation of art and inspire creative thinking. Such as introduced popular new of design style and design elements, telling most excellent of innovation design works and most advanced of design technology means, full using modern information technology and multimedia means to show various learning resources (including new textbook, audio information, multimedia courseware, how to use software tool and get various teaching information from Internet, etc.). That will arouse students' creation enthusiasm and produce inspiration. 
C. Bold reform of teaching methods, development of innovative design-conscious cultivation

- Paying attention to the role change, to inspire students' innovative thinking

Teachers are who pass on his knowledge to students play an important role in teaching and training, but also the important role playing Guide. They should change the traditional method of inculcation in course knowledge point of transmission to become a inspirer and Guide, should focus on encouraging students to innovative thinking that change the mode of trial of an answer or works from the trammels of conventional ideas. Such that to be creative and active thinking and innovative design, the educators will also benefit.

- Using case-driven analysis, heuristic method of teaching

According to the case analysis of heuristic teaching, inspiring students to case design, leading students to innovation and creativity, it is now recognized as an effective mode for educational innovation. Due to combined case analysis with teaching process that can inspire students for more angle thinking, encourage them using different of source material of literature and art, combine class case in the of knowledge points to design, the making issues would be of differences on personalized effect. The so-called works can make students constantly strengthen knowledge points to understand more on a level of knowledge. Meanwhile, the heuristic method of teaching through remodeling and updating of knowledge to encourage students to inconsistent analysis, design a different case and compare analysis reasoning of multiple design, that will enable students foster spontaneous innovation of consciousness and self-confidence, further arouse students' interest in learning and motivation and cultivating innovation consciousness.

- Appropriate adopting of collaborative practice, promoting to form innovation or entrepreneurship team

In today's national good policy to encourage college students' innovation or entrepreneurship during University, for team collaboration between the students themselves, or students and teachers select representative subjects to carry project cooperation, it is very necessary to provides the best environments and conditions for the cultivation of innovative talents. Interaction between student and teacher exchanges in research collaboration not only may put bold design and creativity into the collective works through innovative thinking in collective wisdom together to complete the project, but also exercise and cultivate teamwork cooperation ability and creative ability. During the process, each student in the teamwork will be of great advantage, strong sense of accomplishment and benefit of the future into the community.

- Taking the opening teaching mode in conjunction with market, stimulating students' creative potential
Contemporary design products are applied throughout the community. Theory and practice of students in the school should keep up with times, consistent with the pace of developing production and life in today's society. Through cooperation with enterprises of open education, the students' design skills will be further strengthened and opened innovative design view. At the same time, the studentproductive resource is also brought into better play. As the good creative design works of cooperation may be returned to society of production and services to create social wealth. Even more important is that technical cooperation and exchange between school and enterprise in which students will be exposed to market of a practical design concept and design workflow for combat capabilities, help to open their design view, deepen the understanding of learning book knowledge, foster innovation and creative thinking and capability.

- Encouraging students to participate competition, getting creative inspiration and creative passion

The emergence of a creative talent with driving force that often coming from the stick of faith and zeal for the pursuit has become an indisputable fact. But how to cultivate creative talents provide a showcase to ability level or evaluation stage, it is one of the best means to participate in a competition or contest, as judging criteria and rules are open, fair and impartial.

On encouraging students to actively participate social organization of various competition or contest, it should be special to pay attention on the school organization of various game activities. For example, holding the creative design works exhibition for students their self, reviewed appreciation activity of famous works for various genre celebrity, various project contest of innovative design, application game for new technology of design means, and various forms to encourage and mobilization students participating activities of enthusiasm. So that makes them inspire creative enthusiasm, foster innovation thinking, test their ability and then boost self-confidence. The training practice has shown that the form of encouraging students to actively participate in various design competitions is one of the best practical teaching activities to cultivate and stimulate the students' passion and abilities of independent innovation.

\section{CONCLUSION}

Innovation is the power for driving sustainable development in modern society. The cultivation of the innovative talents is assigned to a University education in the era of the sacred mission and responsibility ${ }^{[5]}$. Under " the mass do pioneering work, the multitude do innovating " national good policy of inspired and encourages, the professional education of Art design mast confront the contradiction with the social needs today. It is very important to remodel new of education concept again, frame talent training mode, reform to teaching way and means and rich practice teaching connotation. For innovative talent type trained, to create good of education environment and build a foster platform for standing out have been urgent and 
imperative. The proposed reinforcement, enrichment and development of practice teaching content, concepts and strategies have a strong operational and useful reference value of cultivating creative talents of art design.

\section{REFERENCE}

[1] Qian Xueshen. Thinking for Scientific Research. Statements made at the first national symposium of thinking. 1984.
[2] He Kekang. Theory of creative thinking DC construction of model and demonstration [M]. Beijing Normal University Publishing Group,2000.3.

[3] Lin Lei. On the cultivation of creative talents of art design in comprehensive universities [J]. China Human. 2013.3K. Elissa, "Title of paper if known," unpublished.

[4] Huang Huaming, Wang Ping, etc. The construction of practice teaching system in Engineering Colleges of art and design[J]. Laboratory research and exploration. 2013.6.

[5] Study on the development strategy of China Academy of art and design, Tsinghua University education research group. Study on the development strategy of China art design education $[\mathrm{M}]$. Tsinghua University Publishing Group,2010. 